\title{
Study of Selected Parameters of Coal Burned in a Combined Heat and Power Plant
}

\author{
Magdalena Paśnikowska-Łukaszuk¹ \\ 1 Faculty of Technology Fundamentals, Lublin University of Technology, ul. Nadbystrzycka 38, 20-618, Lublin, \\ Poland \\ E-mail: m.pasnikowska-lukaszuk@pollub.pl
}

\begin{abstract}
The paper discusses the use of fossil fuels and the process of their extraction in Poland. Hard coal used on a daily basis in one of the Polish combined heat and power plants was described, followed by monthly measurements of coal parameters. Daily and total analyzes of the obtained measurement results of hard coal were carried out in accordance with the applicable standards. The differences in the values of coal from the same source but imported at different time intervals are shown, which result from the weather conditions and the method of hard coal storage. Negative correlations occurred between ash content and calorific value, heat of combustion and volatile matter, as detailed in the work conclusions.
\end{abstract}

Keywords: coal, heat and power plant, energy, combined heat and power

\section{INTRODUCTION}

Fossil fuels are most commonly used in combined heat and power plants [1]. These are energy resources that classify their origin to organic [2]. The main fossil fuels include, first of all, hard coal, lignite, crude oil, natural gas and peat [3]. Although there is more and more talk about switching from fossil fuels to ecological fuels, most combined heat and power (CHP) plants in Poland still use coal, however, thanks to modernized systems and installations, it is possible to reduce coal combustion or modernization CHP plants over switch to biofuels or create biomassfired power units [4]. There are solutions on the market that use biomass from e.g. sunflower [5]. One of the most popular is the willowleaf sunflower [6]. Some plants also use biogas [7]. It is worth adding that for several years Poland has been reducing the amount of coal burned in accordance with the regulations of the European Union. In previous years, over 3 million tons less hard coal was burned as in 2016-2018. Coal is influenced by many factors which then influence the combustion process [8].
Currently, about 20 hard coal mines are operating in Poland. Most of them are located in the vicinity of Upper Silesia $[9,10]$. Hard coal from different mines will differ in their parameters [11]. However, hard coal itself is divided into several types [12]. The most important types of hard coal include: steam coal, gas-steam coal, gas-coking coal, gas coal, ortho-coking coal, meta-coking coal, semi-coking coal, lean coal, anthracite coal, anthracite and meta-anthracite. In domestic stoves, flame, gas-coke and lean coal are most often used. However, the first two have a high volatile content [13]. Anthracite has the lowest volatile content. Detailed types of coal and its use are presented in Table 1.

When it comes to coal consumption over the last two decades, it can be noticed that, according to the data of the Central Statistical Office, the consumption of hard coal in relation to 2005 increased in Mazowieckie (by 27.1\%), Opolskie (by 15.0\%) and Świętokrzyskie (by 24.1\%); in the others there was a decrease [15]. Figure 1 shows the amount of coal used by voivodships in Poland.

Compared to Europe in recent years, it can be seen that Poland is at the top when it comes to 
Table 1. Type of coal [14]

\begin{tabular}{|c|c|c|c|}
\hline Type of coal & Content volatile parts V\% & Short characteristic & The use of coal \\
\hline Steam coal & over 28 & $\begin{array}{l}\text { High volatile matter content, none } \\
\text { or poor sintering ability, long, } \\
\text { strongly glowing flame }\end{array}$ & $\begin{array}{l}\text { Power generation, for all types of } \\
\text { furnaces. }\end{array}$ \\
\hline Gas-steam coal & over 28 & $\begin{array}{l}\text { High volatile matter content, } \\
\text { medium sintering ability }\end{array}$ & $\begin{array}{l}\text { Power generation, for all types of } \\
\text { furnaces. }\end{array}$ \\
\hline Gas coal & over 28 & $\begin{array}{l}\text { High gas and tar efficiency, } \\
\text { significant sinterability }\end{array}$ & $\begin{array}{l}\text { Power generation, grate and pulverized } \\
\text { fuel furnaces, industrial boilers, gas } \\
\text { plants and blends for the production of } \\
\text { coke in coking plants. }\end{array}$ \\
\hline Gas-coking coal & over 28 & $\begin{array}{l}\text { High gas and tar yield, good } \\
\text { sinterability, medium pressure } \\
\text { depressurization }\end{array}$ & $\begin{array}{l}\text { For the production of coke in coking } \\
\text { plants, gas plants and gas-coking plants. }\end{array}$ \\
\hline Ortho-coking coal & from 20 to 31 & $\begin{array}{l}\text { Typical coking coal, medium } \\
\text { volatile matter content good } \\
\text { sinterability, high pressure } \\
\text { depressurization }\end{array}$ & Production of coke in coking plants. \\
\hline Meta-coking coal & from 14 to 28 & $\begin{array}{l}\text { Good sinterability, high pressure } \\
\text { depressurization }\end{array}$ & Production of coke in coking plants. \\
\hline Semi-coking coal & from 14 to 28 & $\begin{array}{l}\text { Low volatile matter content, poor } \\
\text { sinterability, medium pressure } \\
\text { depressurization }\end{array}$ & $\begin{array}{l}\text { For blends for the production of coke } \\
\text { in coking plants; may also be utilized } \\
\text { for power generation in specially } \\
\text { constructed furnaces and for production } \\
\text { of smokeless fuel. }\end{array}$ \\
\hline Lean coal & from 14 to 28 & $\begin{array}{l}\text { Low volatile matter content, none } \\
\text { or poor sinterability, short flame }\end{array}$ & $\begin{array}{l}\text { For blends for the production of coke } \\
\text { in coking plants; may also be utilized } \\
\text { for power generation in specially } \\
\text { constructed furnaces and for production } \\
\text { of smokeless fuel. }\end{array}$ \\
\hline Anthracite coal & from 10 to 14 & $\begin{array}{l}\text { Low volatile matter content, none } \\
\text { sintering ability }\end{array}$ & $\begin{array}{l}\text { For blends for the production of coke } \\
\text { in coking plants; may also be utilized } \\
\text { for power generation in specially } \\
\text { constructed furnaces and for production } \\
\text { of smokeless fuel. }\end{array}$ \\
\hline Anthracite & from 3 to 10 & $\begin{array}{l}\text { Very little part content volatile, no } \\
\text { sintering ability }\end{array}$ & $\begin{array}{l}\text { Power generation in specially } \\
\text { constructed furnaces and for the } \\
\text { production of carbon electrodes. }\end{array}$ \\
\hline Meta-anthracite & to 3 & $\begin{array}{l}\text { Very little part content volatile, no } \\
\text { sintering ability }\end{array}$ & $\begin{array}{l}\text { Power generation in specially } \\
\text { constructed furnaces and for the } \\
\text { production of carbon electrodes. }\end{array}$ \\
\hline
\end{tabular}

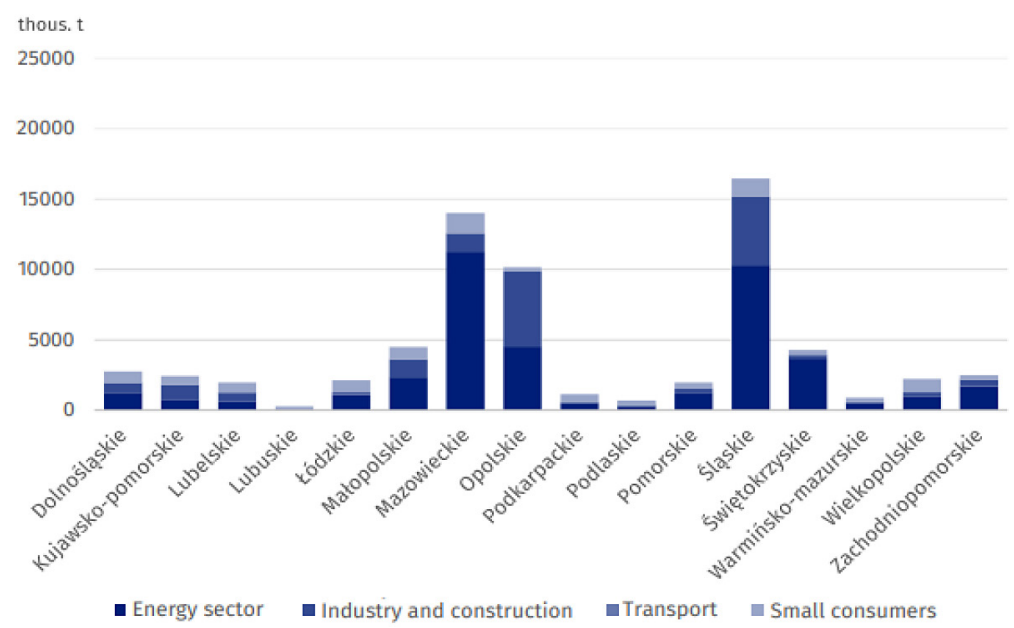

Fig. 1. Consumption of hard coal in 2019 in Poland [15]

hard coal mining [16]. Heat and power plants try to use various coal mixtures to obtain the best energy effects, but also to minimize the emission of elements to the atmosphere by selecting the most advantageous coal $[17,18]$. In order to check the monthly parameters of coal, the results were collected from one CHP plant in Poland, which uses hard coal for energy production $[19,20]$. The 
collected data included such parameters of coal as: moisture, ash content, sulfur content, heat of combustion, calorific value, and volatile parts [21]. The individual parameters were made more precise in order to obtain as many results as possible, which may prove the remaining components of carbon factors $[22,23]$. The aim of this study is to present daily changes in hard coal parameters. With the help of the performed tests, it is possible to observe the influence of environmental factors on the quality of hard coal burning.

\section{MATERIAL AND METHODS}

Gas coal samples were taken in an OR-type steam boiler. The OR boiler is a steam boiler used in a combined heat and power plant. It is the main boiler cooperating with EKM (steam) and WP (water-dust) boilers. The OR boiler in the CHP plant in question is the OR50-N model. His basic technical data include rated steam capacity (50 $\mathrm{t} / \mathrm{h}$ ), minimum steam capacity $\geq 30.0 \mathrm{t} / \mathrm{h}$, steam pressure at the outlet 67 bar, steam temperature at the outlet $490.0 \pm 5 \mathrm{C}^{\circ}$, steam temperature for min. steam capacity $420.0 \mathrm{C}^{\circ}$ and feed water temperature $105.0 \mathrm{C}^{\circ}$. The tested hard coal is used in a combined heat and power plant, which in 2019 produced 101,477 MWh/year of electricity and heat production was $1,668,312 \mathrm{GJ} /$ year. In the analyzed samples collected in one of the Polish heat and power plants, a variety of parameters can be noticed. It should be added that samples were taken every day at similar times of the day. In the parameters related to moisture, the transient moisture content $\mathrm{W}^{\mathrm{ex}}$, analytical moisture $\mathrm{W}^{\mathrm{a}}$, total moisture $\mathrm{W}^{\text {tr }}$ and moisture content in air-dry coal $\mathrm{W}^{\mathrm{h}}$ called hygroscopic moisture were checked. The weighting method was used to determine the coefficients, and the unit is expressed as a percentage. The moisture content was tested using the PN-80/G-04511 standard. The considered gas coal in its working condition had a calorific value of $21,755 \mathrm{~kJ} / \mathrm{kg}$. In the tested samples, the content of analytical ash $\mathrm{A}^{\mathrm{a}}$ and ash in the working fuel $\mathrm{A}^{\mathrm{r}}$ was also checked. The ash content was tested according to the PN-G-04560: 1998 standard. The study was also performed using the weight method using the percentage unit. The total analytical sulfur content $S_{t}^{a}$ and the sulfur content in the working fuel $S_{t}^{r}$ were also examined. The high-temperature combustion method with IR detection was used to perform the measurement [24,
25]. In the analyzed hard coal, the sulfur content was tested in accordance with the PN-G-04584: 2001 standard. In the obtained tests performed using the calorimetric method from the calculations, the analytical calorific value $\mathrm{Q}_{\mathrm{i}}{ }^{\mathrm{a}}$ and the calorific value in the working fuel $\mathrm{Q}_{i}{ }_{\mathrm{r}}^{\mathrm{r}}$ were obtained. [26, 27]. The heat of combustion was tested according to $\mathrm{PN}-81 / \mathrm{G}-04513$. The last parameter tested was volatile matter. As with the previous parameters, the analytical value $\mathrm{V}^{\text {a }}$ and the value in an ashless $\mathrm{V}$ daf sample were tested here. The measurement was made by the weight method and the results are expressed as a percentage unit. Measurements were made in accordance with the PN-G-04516: 1998 standard.

\section{RESULTS}

The results were collected from the 26 days of the reporting period, the last two days are included in other the reporting period, therefore only 26 days of the month were selected. The results of moisture content from 26 days are presented in Table 2. The table shows the measurements made in the winter. The samples were taken from the OR 50-N boiler.

It can be noticed that the highest transient moisture occurred on the fourth measurement day, and on the ninth and tenth day, transient moisture was the lowest. The result could be due to the same weather conditions outside where the coal is stored. The distribution of all moisture is shown in the diagram in Figure 2. The results of ash content are shown in Figure 3.

The collected data of sulfur content in coal samples are presented in Table 3. The results are shown in percentage units. The ash content shows a downward trend until the 16th day. This may be due to a change in the furnace settings and the weather conditions.

The samples tested in the middle of the month contained the most sulfur. This could be caused by a change of coal that was stored with the remaining coal in the combined heat and power plant. That is, the stored coal often consists of several deliveries from the same source, however, the parameters of the coal may change when it is extracted from different areas of the extraction site. With the increase in the total sulfur content, the value of the tested sulfur in the working fuel also increases. As for the heat of combustion $\mathrm{Q}_{\mathrm{s}}$, it was observed that the tested coal shows values 
Table 2. Moisture content in the tested coal

\begin{tabular}{|c|c|c|c|c|}
\hline \multicolumn{5}{|c|}{ Moisture } \\
\hline \multirow{2}{*}{ Day } & $W^{e x}$ & $W^{a}$ & $W^{h}$ & $W_{t}^{r}$ \\
\hline & $\%$ & $\%$ & $\%$ & $\%$ \\
\hline 1 & 6.6 & 2.1 & 2.4 & 8.8 \\
\hline 2 & 7.3 & 2.4 & 2.5 & 9.6 \\
\hline 3 & 8.2 & 2 & 2.2 & 10.2 \\
\hline 4 & 8.4 & 2.2 & 2.1 & 10.3 \\
\hline 5 & 7.3 & 2.1 & 2.1 & 9.2 \\
\hline 6 & 7.8 & 2.3 & 2.7 & 10.3 \\
\hline 7 & 6.8 & 2.2 & 2.9 & 9.5 \\
\hline 8 & 7.5 & 2.5 & 3 & 10.3 \\
\hline 9 & 6 & 2.2 & 2.2 & 8.1 \\
\hline 10 & 6 & 2.2 & 2.2 & 8.1 \\
\hline 11 & 7.2 & 2.8 & 2.4 & 9.4 \\
\hline 12 & 7.6 & 2.3 & 2.3 & 9.7 \\
\hline 13 & 7.9 & 1.9 & 2 & 9.7 \\
\hline 14 & 7.9 & 2.1 & 2.1 & 9.8 \\
\hline 15 & 8 & 1.7 & 1.8 & 9.7 \\
\hline 16 & 8.2 & 2.2 & 2.3 & 10.3 \\
\hline 17 & 7.8 & 2 & 2.2 & 9.8 \\
\hline 18 & 8.3 & 1.9 & 2 & 10.1 \\
\hline 19 & 8.3 & 1.8 & 1.8 & 10 \\
\hline 20 & 7.1 & 2.2 & 2.2 & 9.1 \\
\hline 21 & 7.8 & 1.6 & 1.8 & 9.5 \\
\hline 22 & 8 & 1.8 & 1.8 & 9.7 \\
\hline 23 & 7.6 & 2.2 & 2.4 & 9.8 \\
\hline 24 & 8.2 & 2.3 & 2.4 & 10.4 \\
\hline 25 & 8.1 & 2.1 & 2.1 & 10 \\
\hline 26 & 8.1 & 2.2 & 2.2 & 10.1 \\
\hline
\end{tabular}

Table 3. Results of sulfur content

\begin{tabular}{|c|c|c|}
\hline \multicolumn{3}{|c|}{ Sulfur } \\
\hline \multirow{2}{*}{ Day } & $S_{t}{ }^{a}$ & $S_{t}{ }^{r}$ \\
\hline & $\%$ & $\%$ \\
\hline 1 & 0.63 & 0.59 \\
\hline 2 & 0.61 & 0.56 \\
\hline 3 & 0.59 & 0.54 \\
\hline 4 & 0.64 & 0.59 \\
\hline 5 & 0.62 & 0.57 \\
\hline 6 & 0.61 & 0.56 \\
\hline 7 & 0.56 & 0.52 \\
\hline 8 & 0.58 & 0.53 \\
\hline 9 & 0.58 & 0.55 \\
\hline 10 & 0.58 & 0.55 \\
\hline 11 & 0.6 & 0.56 \\
\hline 12 & 0.61 & 0.56 \\
\hline 13 & 0.6 & 0.55 \\
\hline 14 & 0.68 & 0.63 \\
\hline 15 & 0.7 & 0.64 \\
\hline 16 & 0.66 & 0.61 \\
\hline 17 & 0.65 & 0.6 \\
\hline 18 & 0.65 & 0.6 \\
\hline 19 & 0.64 & 0.59 \\
\hline 20 & 0.6 & 0.56 \\
\hline 21 & 0.63 & 0.58 \\
\hline 22 & 0.59 & 0.54 \\
\hline 23 & 0.63 & 0.58 \\
\hline 24 & 0.66 & 0.61 \\
\hline 25 & 0.65 & 0.6 \\
\hline 26 & 0.65 & 0.6 \\
\hline
\end{tabular}

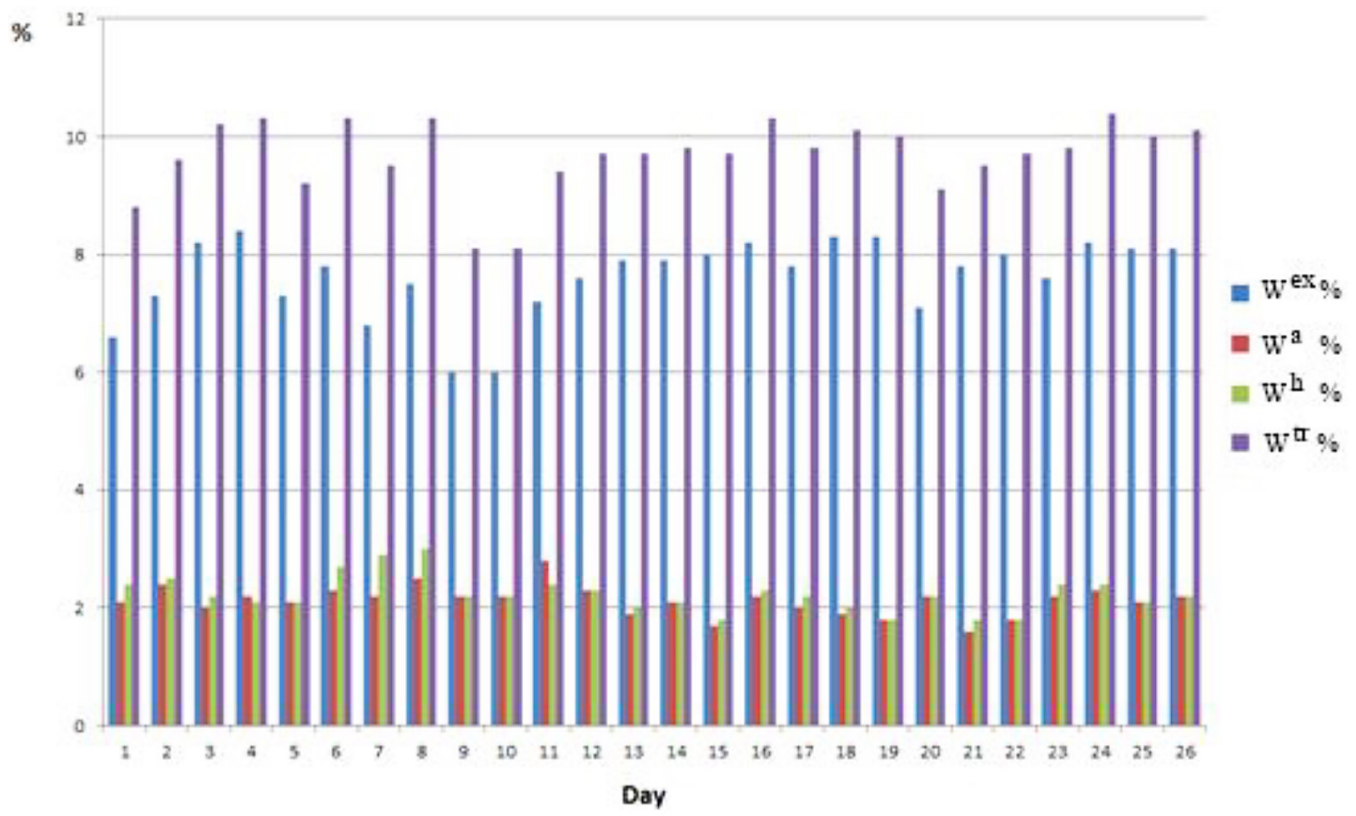

Fig. 2. Distribution of all moisture 


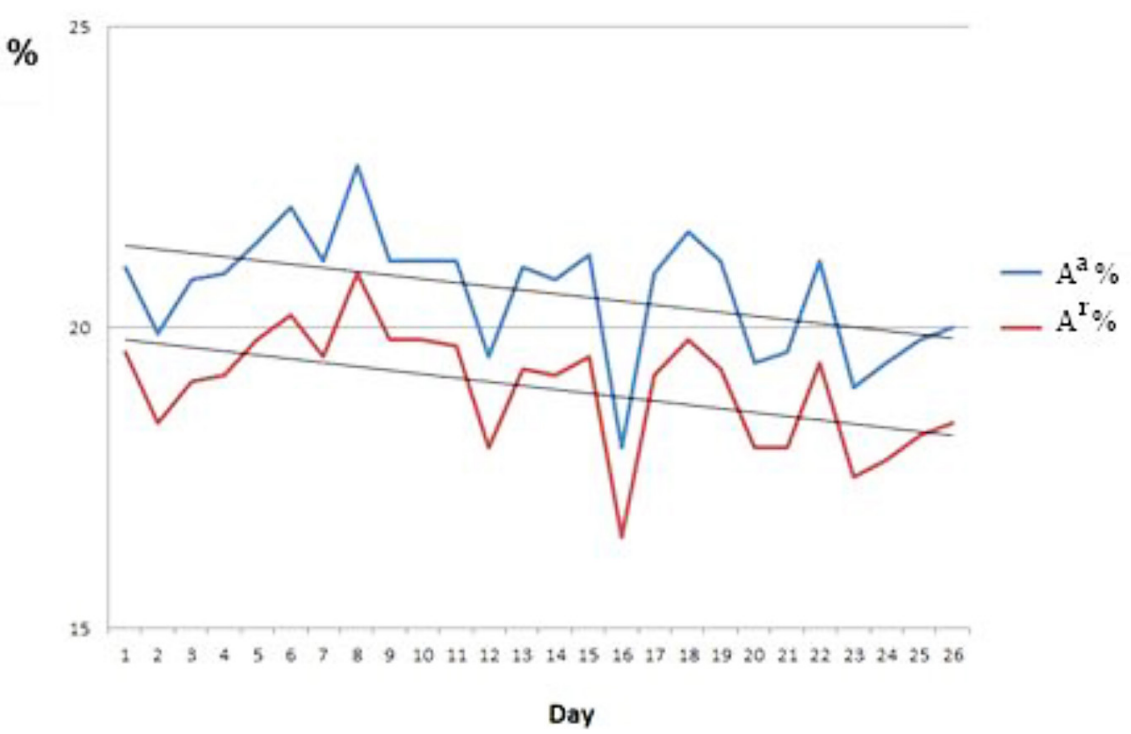

Fig. 3. Ash content measurement results

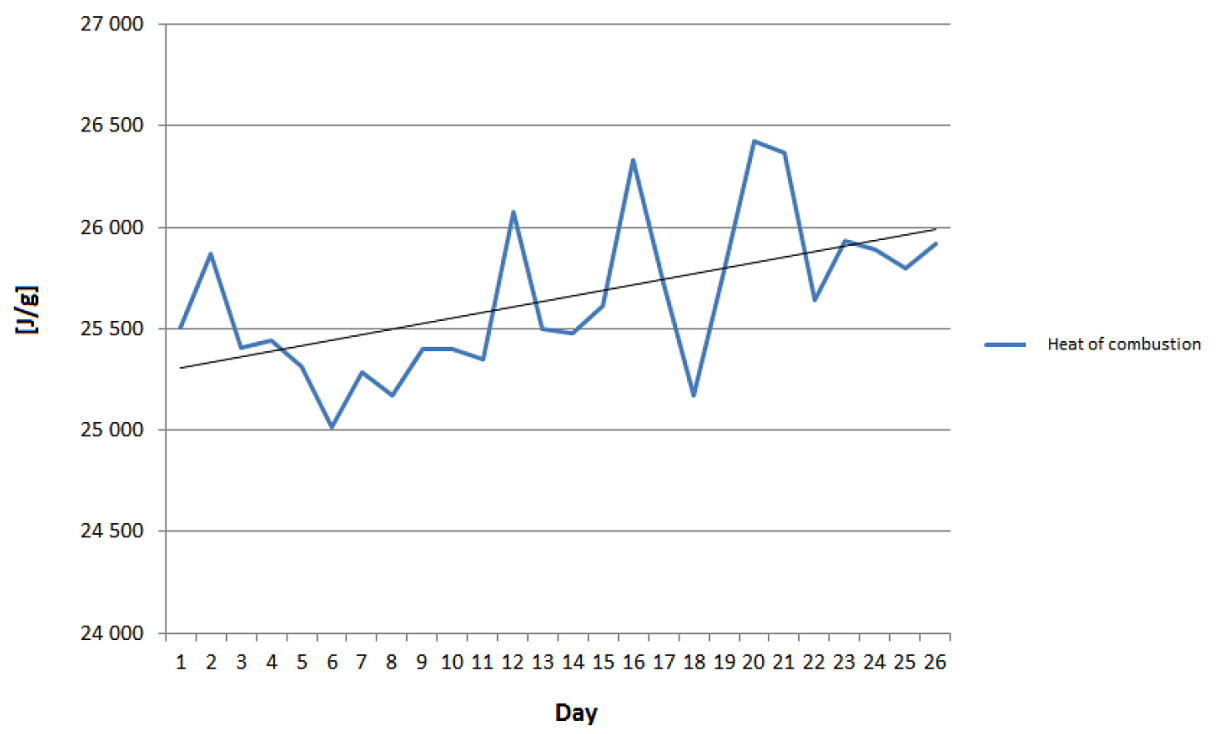

Fig. 4. Combustion heat measurement results

above $25,000 \mathrm{~J} / \mathrm{g}$. The maximum obtained measurement was $26,423 \mathrm{~J} / \mathrm{g}$. Figure 5 shows the results obtained from the measurement of the heat of combustion.

Similar values were found when measuring the calorific value. The measured thermal effect is related to the weight of the sample. The measurement method consists in the complete and complete combustion of the fuel sample $\mathrm{w}$ oxygen atmosphere at a specific pressure in the calorimetric bomb and measuring the gain water temperature in the calorimetric vessel and determining corrections for additional effects thermal [28, 29]. The ARX (AutoRegressive with eXogenous input) [30] model fit (Fig. 6) and the transfer function model (Fig. 7) were used to illustrate the data distribution. The signal of the ARX model was generated from two calorific values as shown in Figure 5. The ARX model is a discrete input-output model for stochastic processes. You can see the consequency between the measurements and the correctness of the measurement taken, which is also within the tolerance of the measurements.

A certain dependence regarding the volatile parts in the ashless sample was noticed. Where there was a high level of total sulfur, there was also a high level of volatile matter. The highest volatile matter content was read on the eleventh day. The amount of volatile matter in the analytical sample was $31.14 \%$ on that day. Figure 8 shows the dependencies between the volatile matter content and the total sulfur content. 


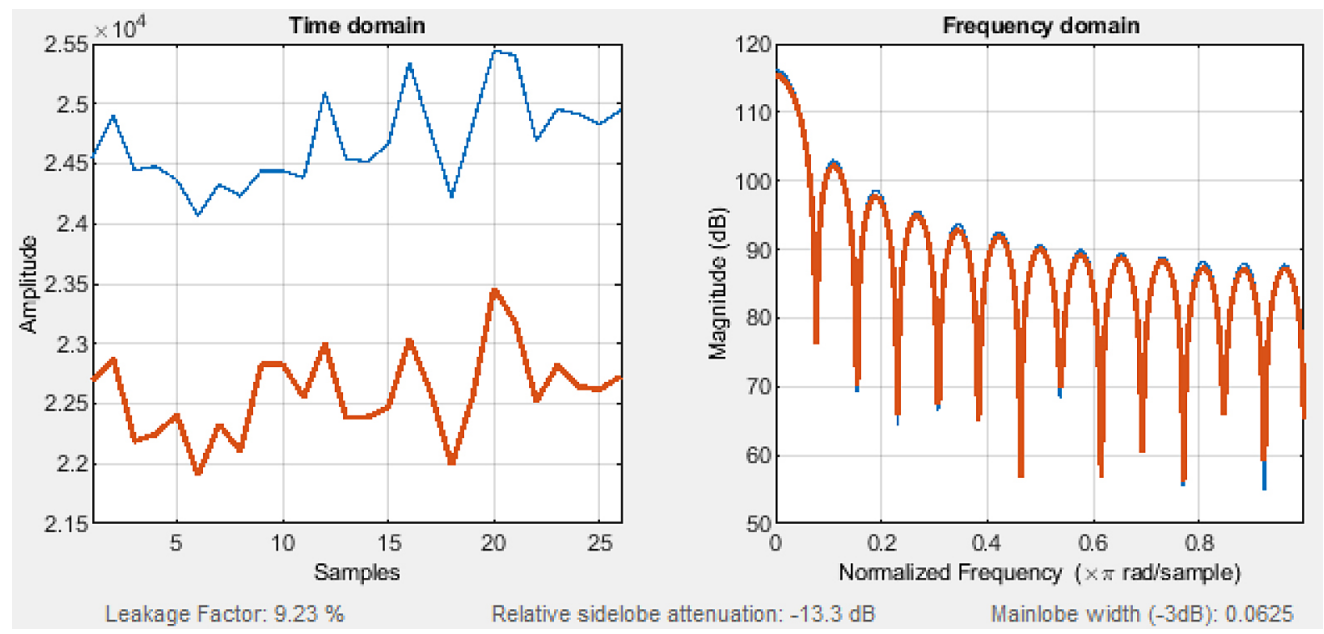

Fig. 5. Calorific value measurements using the signal processing toolbox

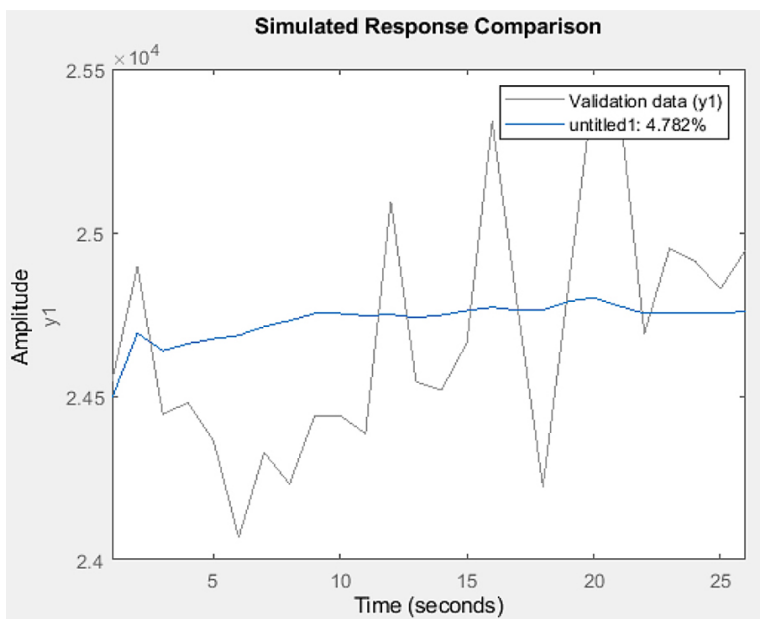

Fig. 6. ARX model fit

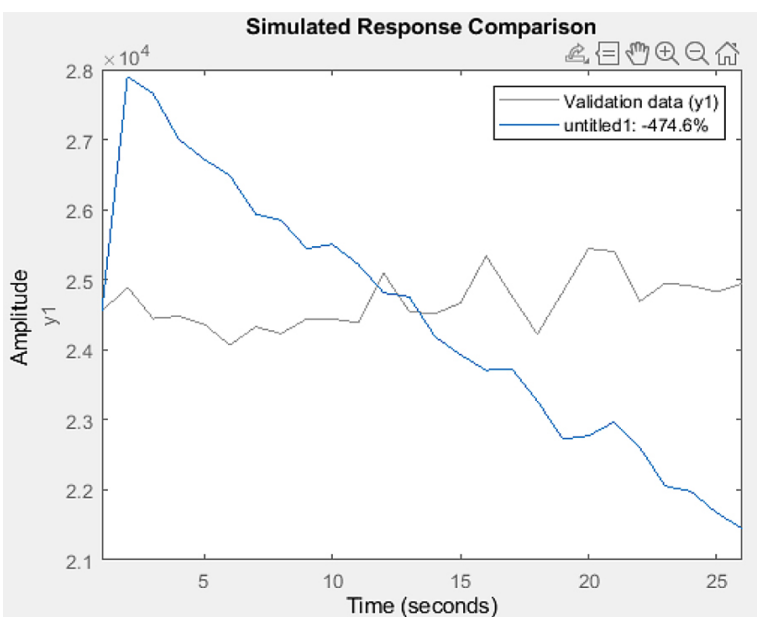

Fig. 7. Transfer function model fit

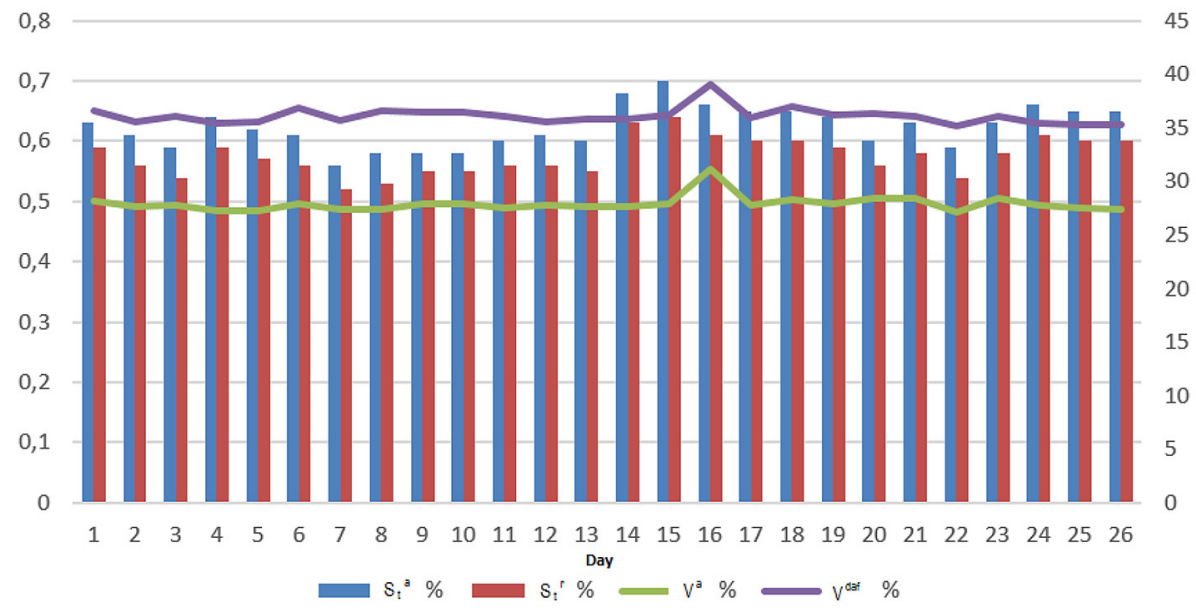

Fig. 8. The dependencies between total sulfur content and volatiles

In order to illustrate the dependencies, the correlations between the parameters of coal were investigated with the use of the R program tools. The $\mathrm{R}$ language is widely used among and data miners for developing statistical software [31].
The $\mathrm{R}$ program is developed by $\mathrm{R}$ Core Team. The results are shown in Figure 9. The presented correlations show how the parameters of coal change with respect to each other. All parameters were tested in accordance with the standards 


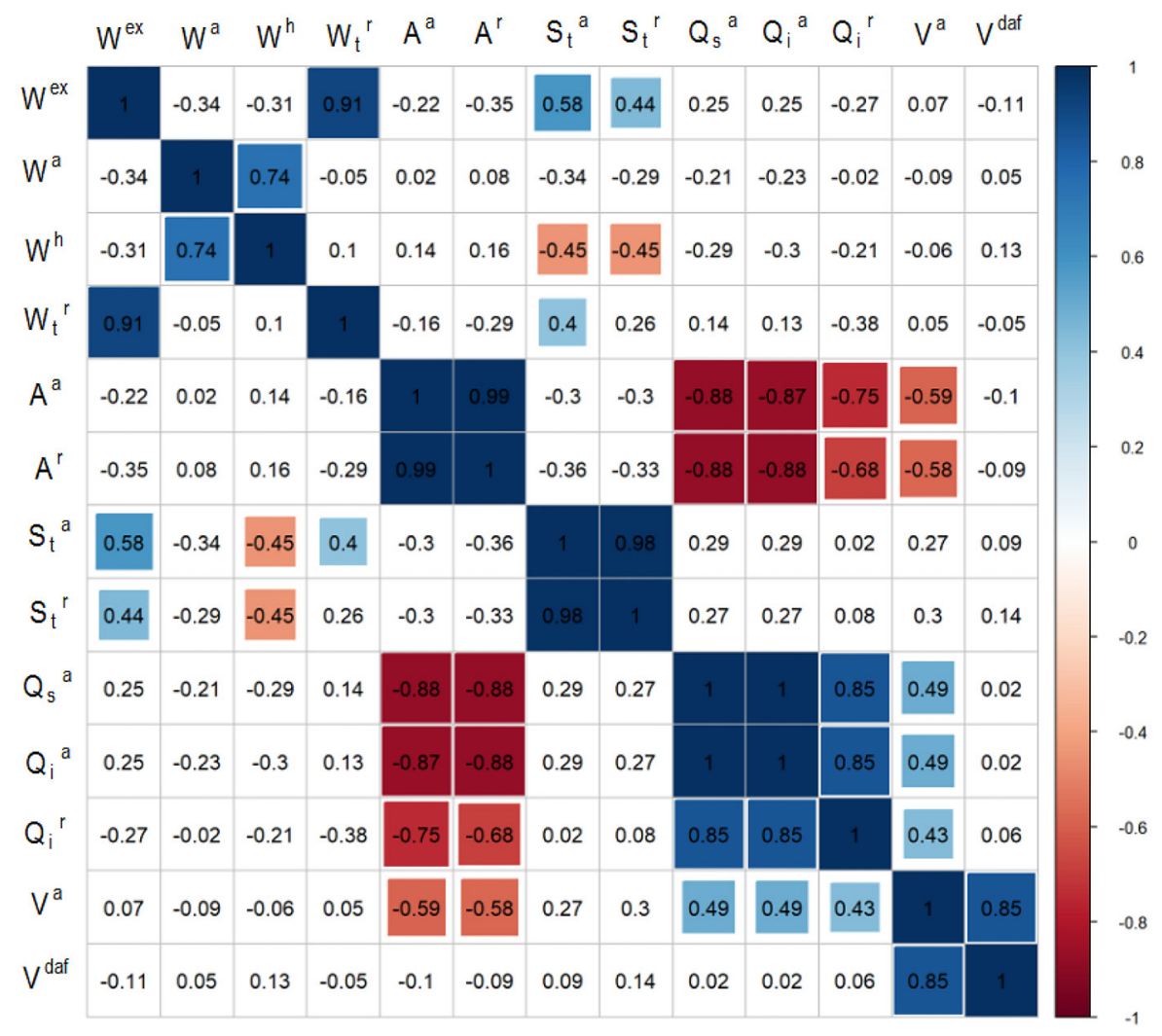

Fig. 9. Correlations between coal parameters.

\section{CONCLUSIONS}

The same measurement results were observed on days 17 and 18 . This could be due to the same coal charge to be burned. When analyzing the parameters of coal, it was noticed that the parameters concerning the ash content and the volatile matter content are negatively correlated with the calorific value. The same applies to the correlation between the ash content and the heat of combustion This correlation is also negative. There was a significant positive correlation between the calorific value and volatiles. Positive correlation occurs between the transient moisture content and the total moisture content, and that the moisture in the analytical sample correlates with the moisture content in air-dry carbon. This means that as the first factor increases, so does the second. A positive correlation, but lower than in other cases, also occurs between the total sulfur content in the analytical sample and the tested sulfur in the working fuel, as well as between the sulfur content and the transient moisture content. Positive correlations also occurred between the heat of combustion and the calorific values. Negative correlations occurred between the ash content and the calorific value, combustion heat and volatile parts. In the presented article, the intended goal was achieved.

\section{REFERENCES}

1. Nyga-Łukaszewska, H., Aruga, K., Stala-Szlugaj, K. ( 2020). Energy security of Poland and coal supply: Price analysis. Sustainability, 2020, 12, 2541.

2. Mills, S., (2014). Prospects for coal and clean coal technologies in Turkey, IEA Clean Coal Centre.

3. Burmistrz, P., Kogut, K., Marczak, M., Zwoździak, J. (2016). Lignites and subbituminous coals combustion in Polish power plants as a source of anthropogenic mercury emission. Fuel Process. Technol., 152, 250-258.

4. Tillman, D. (2000). Biomass cofiring: The technology, the experience, the combustion consequences. Biomass Bioenergy, 19, 365-384.

5. Debarshi, M., Pinakeswar, M., Vijayanand, M. (2018). Synergistic Effects in Gasification of Coal/ Biomass Blends: Analysis and Review. Coal and Biomass Gasification, 473-497.

6. Mudryk, K., Wróbel, M. (2012). Willowleaf sunflower helianthus salicifolius a. Dietr. - for energy purposes, Agricultural engineering, 2(136), 1, 249256. (in Polish) 
7. Black, B. (2002). Organic planning: the intersection of nature and economic planning in the early Tennessee Valley Authority, J. Environ. Policy Plan., 4 (2), 157-168.

8. Balat, M. (2007). Influence of Coal as an Energy Source on Environmental Pollution, Energy Sources, Part A: Recovery, Utilization, and Environmental Effects, 29, 581-589.

9. Suwała, W., Wyrwa, A., Olkuski, T. (2017). Trends in coal use - global, EU and Poland, IOP Conf. Series: Materials Science and Engineering, 268, 012003.

10. Kuchler, M., Bridge, G. (2018). Down the black hole: Sustaining national socio-technical imaginaries of coal in Poland, Energy Research \& Social Science, 41, 136-147.

11. Pawlak-Kruczek, H., Lewtak, R., Plutecki, Z., Baranowski, M., Ostrycharczyk, M., Krochmalny, K., Czerep, M., Zgora, J., Niedzwiecki, L. (2018). The Impact of Predried Lignite Cofiring With Hard Coal in an Industrial Scale Pulverized Coal Fired Boiler. ASME. J. Energy Resour. Technol., 140(6).

12. Ozga, M., Borowski, G. (2018). The use of granulation to reduce dusting and manage of fine coal, Journal of Ecological Engineering, 19, 3, 218-224.

13. Yang, L, Zhang, B, Wang, KH, Ma, DR, Sheng, ZY. (2019). Conversion Characteristics of Combustible Particles from Coal-fired Flue Gas in WFGD and WESP. Huan Jing ke Xue= Huanjing Kexue, 40(1), 121-125.

14. Paździora, J. (1988). Design of undergroud hardcoal mines. PWN, Warsaw, p. 28.

15. Consumption of fuels and energy carriers in 2019. (2020), Statistics Poland Warsaw, access: stat.gov.pl.

16. Vehmas, J., Kaivo-oja, J., Luukkanen, J. (2018). Energy efficiency as a driver of total primary energy supply in the EU-28 countries - incremental decomposition analysis. Heliyon, 4(10).

17. Rybak, Au., Rybak, Al. (2018), The future of hard coal as a guarantor of energy security in Poland, Papers SGEM2018.

18. Xu, C., Xu, G., Zhao, S., Dong, W., Zhou, L., Yang, Y. (2016). A Theoretical Investigation of Energy Efficiency Improvement by Coal Pre-Drying in Coal Fired Power Plants, Energy Convers Manage., 122, 580-588.

19. Wójcicka-Migasiuk, D., Paśnikowska-Łukaszuk, M. (2019). Simulation Analysis of Fuel Mixture Influence on the Effects of Operation of Selected Steam Boilers in Municipal Districts. Journal of Ecological Engineering, 20(10), 54-62.
20. Wójcicka-Migasiuk, D., Paśnikowska-Łukaszuk, M. (2018). Formulations of parametric models for energy and power system elements in the aspect of control quality improvements, Rynek Energii, 136, $3,82-88$

21. Simeonova, T., Benkova, M., Nenova, L., Atanassova, I. (2018). Chemical Composition of Soil Solutions of Technosols from a Coal Mine Region in SouthEastern Europe. Bulgarian Journal of Soil Science, 3, 1 .

22. Korski, J., Tobór-Osadnik, K., Wyganowska, M. (2016), Reasons of problems of the Polish hard coal mining in connection with restructuring changes in the period 1988-2014. Resour. Policy, 48, 25-31.

23. Kaliski, M., Sikora, A., Szurlej, A. (2014), Hard coal in the energy policy of Poland. Energy Policy Journal, 2, 17, 3, 7-18. (in Polish)

24. Zhao, S., Pudasainee, D., Duan, Y., Gupta, R., Liu, M. (2019). A review on mercury in coal combustion process: Content and occurrence forms in coal, transformation, sampling methods, emission and control technologies. Prog. Energy Combust. Sci., 73, 26-64.

25. Dziok, T., Strugała, A., Baic, I., Olszewska, D. (2020). Valorization Method for Hard Coal as Fuel for Nonindustrial Combustion Installations with Special Regard to Reduction of Mercury Content, Energy \& Fuels, 34 (3), 2980-2988.

26. Klatka, S. T., Malec, M., Ryczek, M. (2019). Analysis of Spatial Variability of Selected Soil Properties in the Hard Coal Post-Mining Area. Journal of Ecological Engineering, 20(3), 185-193.

27. Ghose, M.K. (1989). Land reclamation and protection of environment from the effect of coal mining operation. Mine technology, 10(5), 35-39.

28. Kotlicki, T. (2007). Determination of the heat of combustion of coal using a calorimeter. Lodz University of Technology (in Polish).

29. Khosravi, A., Olkkonen, V., Farsaei, A., Syri, S. (2020). Replacing hard coal with wind and nuclear power in Finland- impacts on electricity and district heating markets, Energy, Elsevier, 203(C).

30. Diversi, R., Guidorzi, R.,Soverini, U., (2010). Identification of ARX and ARARX Models in the Presence of Input and Output Noises, European Journal of Control, 3, 242-255

31. Fox, J., Andersen, R. (2005). Using the R Statistical Computing Environment to Teach Social Statistics Course, Department of Sociology, McMaster University. 